\title{
Development of Disease and Growth on Six Scion/Rootstock Combinations of Citrus Seedlings under Huanglongbing Pressure
}

\author{
Sri Widyaningsih ${ }^{1,2}$, Sri Nuryani Hidayah Utami ${ }^{2}$, Tri Joko ${ }^{2} \&$ Siti Subandiyah ${ }^{2,3}$ \\ ${ }^{1}$ Indonesian Citrus and Subtropical Fruits Research Institute, Indonesian Agency of Agriculture Research and \\ Development, Ministry of Agriculture, Batu, East Java, Indonesia \\ ${ }^{2}$ Faculty of Agriculture, Universitas Gadjah Mada, Yogyakarta, Indonesia \\ ${ }^{3}$ Research Centre of Biotechnology, Universitas Gadjah Mada, Yogyakarta, Indonesia \\ Correspondence: Sri Widyaningsih, Indonesian Citrus and Subtropical Fruits Research Institute, Indonesian \\ Agency of Agriculture Research and Development, Ministry of Agriculture, P.O. Box 22, Batu, East Java, \\ Indonesia. E-mail: sri.wiwied74@gmail.com
}

Received: March 6, 2017

doi:10.5539/jas.v9n6p229
Accepted: April 20, $2017 \quad$ Online Published: May 15, 2017

URL: https://doi.org/10.5539/jas.v9n6p229

\begin{abstract}
Huanglongbing (HLB) disease is the most serious threat to citrus production in Indonesia. Commonly, the planted rootstocks/scion varieties expressed severely damaged to HLB. This research aimed to study effects of six citrus rootstock/scion combination of varieties on intensity of HLB disease, presence of Candidatus Liberibacter asiaticus (CLas), and growth of the seedlings. The grafting combination of three rootstock varieties: Japansche citroen (Citrus limonia Osbeck), Volkamer lemon (C. volkameriana V. Ten \& Pasq), 'Salam' (local name), and two scions varieties: 'Siem Pontianak' (C. nobilis Lour) and 'Keprok Tejakula'. 'Keprok Tejakula' ( $C$. reticulata Blanco) were used for examination the effect rootstock/scion combination to HLB. Based on symptoms, the onset of disease intensity was observed in eight months after CLas inoculation, except on 'Salam' rootstock. The status of $C$ Las inoculation, rootstock/scions varieties and the duration of plant infection influenced to $C$ Las titers. There were inconsistency between HLB symptoms and CLas titers. According to measurement of plant height, and diameter of rootstocks and scion stem, the plant growth of Volkamer lemon rootstock grafted with 'Siam Purworejo' scion or 'Keprok Tejakula' scion was better than grafted with Japansche citroen and 'Salam' rootstocks. Japansche citroen rootstock was more susceptible to HLB than Volkamer lemon and 'Salam' rootstocks. Combination of rootstock/scion varieties affected plant tolerance against HLB.
\end{abstract}

Keywords: growth, huanglongbing, 'Keprok Tejakula', rootstock, scion, 'Siam Purworejo'

\section{Introduction}

Citrus huanglongbing (HLB) is caused by a phloem-limited gram-negative bacterium, Candidatus Liberibacter asiaticus (CLas). Liberibacter cluster from Pacific were identical on their own compared with Asian isolates (Subandiyah et al., 2000). HLB is one of the most serious citrus diseases worldwide, because it still has no effective control method and citrus yield is greatly declined while the disease spreads rapidly in orchards. Grafting could be effective to transmit the bacteria with the rate of infection level reached $100 \%$ in 120 days after inoculation. CLas might be easily propagated by buds taken from non-symptomatic but infected branches and multiplication occurred most quickly in young citrus plants. Folimonova et al. (2009) grouped citrus genotypes into four categories (sensitive, moderately tolerant, tolerant and variable) based on severity of HLB symptoms and continuous growth of the CLas-inoculated plants. While, according to reaction with HLB pathogen, Ahmad et al. (2011) classified citrus species into very susceptible, susceptible, and tolerant.

Some predictions of plant resistance or tolerance to HLB within citrus and citrus relatives under field condition have been observed, although there was no HLB-resistant on commercial citrus varieties. Scion/rootstock combination showed the differences on tolerance to HLB. Albrecht et al. (2016) studied that many metabolites in the tolerant cultivars were expressed in higher concentrations and lower availability of specific sugars which was necessary for pathogen survival. It might had an important role in the decreased disease severity. According to Ramadugu et al. (2016), resistance and tolerance to HLB disease in different citrus accessions depended on many 
factors, including ability of vector colonization, patogen propagation, infection process and plant recovery from infection.

Study of the level of tolerance to HLB is important for resistance breeding program, and the development of alternative horticultural practices which can control and mitigate the devastatingly effects of this disease. Use of a tolerant rootstock is suggested as an effective means for ameliorating crop losses under endemic of huanglongbing (Bowman et al., 2016). Rootstock varieties did not induce high-level resistance to scion in early infection with CLas. However, tree performance was improved and tolerance to HLB increased on some rootstocks (Albrecht et al., 2012). Stover et al. (2016) stated that the two criterias most widely applied in assessing HLB resistance were symptoms and higher early pathogen titer. It might not relate with the lowest growth and cropping.

Several rootstock varieties planted in Indonesia were generally grafted with 'Siam', 'Keprok', and pumello scion. Japansche citroen rootstock commonly grown in Indonesia, 'Salam' rootstock limited in Tulungagung, East Java, Indonesia, while the Volkamer lemon rootstock was not widely used because lack of seed availability. Trees on Japansche citroen rootstock was known to be severely infected by HLB on citrus orchard production in Indonesia. On the other hand, tolerance of trees on Volkamer lemon and 'Salam' rootstocks was unknown yet.

The information of tolerance to HLB on rootstock/scion combination can be necessary in management of HLB both in nusery and field. Healthy citrus nursery is the starting point for controlling HLB and reducing the source of inoculum by eliminating HLB-infected trees and controlling the citrus psyllids. Frequency of inspection to detect symptomatic plants before eradication treatment affected the success of HLB control by decreasing the escape plants (asymptomatic and non visual detectable diseased plants) (Bassanezi et al., 2013). McCollum et al. (2016) demonstrated that results obtained from screening susceptibility of citrus germplasm to HLB in greenhouse experiment was in line with tendence observed in the citrus orchard. The objective of this study was to study the effect of six citrus rootstock/scion combinations of varieties on huanglongbing disease intensity, presence of Candidatus Liberibacter asiaticus (CLas), and growth of citrus seedling.

\section{Method}

\subsection{Plants, Sources of Inoculum, Rootstock/Scion Varieties and Inoculations}

The grafting combinations of three rootstock varieties: Japansche citroen (Citrus limonia Osbeck), Volkamer lemon (C. volkameriana V. Ten \& Pasq), 'Salam' (local name), and 2 scions varieties: 'Siem Pontianak' (C. nobilis Lour) and 'Keprok Tejakula' (C. reticulata Blanco) were used for testing the tolerance of citrus to HLB. All plants were grown in 2-liter polybags. The successful of grafting was indicated by the survival scion more than 3 months after grafting. Eight months old of seedlings from each of rootstock/scion combinations was inoculated with three pieces of $C$ Las infected bark tissues per plant. The sources of $C$ Las inoculum were symptomatic branches of 6-year-old Japansche citroen/'Batu 55' (C. reticulata Blanco) infected tree, which positively HLB-detected by PCR (Polymerase Chain Reactions) analysis. As a control, each of rootstock/scion combinations was mock-inoculated with disease-free tissue pieces. The experiments were conducted by completely randomized design with 5 replications. Plants were placed at the endemic psyllids vector nursery.

\subsection{Disease Intensity}

Disease intensity was observed on 4,8 and 12 months after treatment. The disease intensity calculated by the following formula (Shokrollah et al., 2011).

$$
\text { The disease intensity }=\frac{\sum(\mathrm{a} \times \mathrm{b})}{\mathrm{N} \cdot \mathrm{Z}} \times 100
$$

Where, $\sum(\mathrm{a} \times \mathrm{b})=$ Number of symptomatic plants and corresponding score; $\mathrm{N}=$ total number of plant samples; $\mathrm{Z}=$ the highest score.

Score was used to observe of HLB disease intensity based on the lowest symptoms to the highest symptoms, which was developed by McKinney (1923) (Table 1). 
Table 1. Score and description of HLB symptoms

\begin{tabular}{ll}
\hline Score & Description \\
\hline 0 & Leaves on branch asymptomic \\
1 & Leaves on branch showing mild-mottling \\
2 & Leaves on branch showing mottling \\
3 & Leaves on branch showing mottling with corking \\
4 & Leaves on branch showing mild-chlorosis \\
5 & Leaves on branch showing chlorosis \\
6 & Leaves on branch showing chlorosis with corking \\
7 & Leaves on branch showing mild-Fe deficiency-like symptom \\
8 & Leaves on branch showing Fe deficiency-like symptom \\
9 & Leaves on branch showing Fe deficiency-like symptom with corking \\
10 & Leaves on branch showing mild-interveinal chlorosis (Zn deficiency-like symptom) \\
11 & Leaves on branch showing interveinal chlorosis (Zn deficiency-like symptom) \\
12 & Leaves on branch showing interveinal chlorosis (Zn deficiency-like symptom) with corking \\
13 & Leaves on branch abscised, branch desiccated \\
\hline
\end{tabular}

\subsection{Candidatus Liberibacter Asiaticus (CLas) Titers by Real-Time PCR Analysis}

The total DNA was extracted from $0.3 \mathrm{~g}$ midrib of leaves sample by using CTAB buffer extraction that was modified to lysed cell walls of plants (Anonymous, 2002). The presence of CLas was detected by real-time PCR. The extrated DNA $(1 \mu \mathrm{l})$ was used as template for real-time PCR. Quantification of bacterial titers used a series of primer LJ900fr, forward primer (5-GCCGTTTTAACACAAAAGATGAATATC-3), and reverse primer (5-ATAAATCAATTTGTTCTAGTTTACGAC-3) (Zhou et al., 2011). Real-time PCR reaction mix used $20 \mu 1$ contained $10 \mu \mathrm{l}$ of universal real-time mix with SYBR green (Kappa), $1 \mu 1$ of each primer, $1 \mu 1$ of DNA sample (50 ng/ $\mu \mathrm{l}$ ), and $7 \mu 1 \mathrm{H}_{2} \mathrm{O}$. Running reactions used real-time PCR machine (Biorad) under following conditions of pre-denaturation at $95^{\circ} \mathrm{C}$ for $3 \mathrm{~min}$, then followed by 40 cycles of denaturation at $95{ }^{\circ} \mathrm{C}$ for $3 \mathrm{~s}$. The cycles were separated by annealing at $60{ }^{\circ} \mathrm{C}$ for $60 \mathrm{~s}$ at the end of each stage. Melt curve of extension at $90{ }^{\circ} \mathrm{C}, 0.5{ }^{\circ} \mathrm{C}$ increments for 10 seconds. Detection of the presence of $C$ Las bacteria with real-time PCR was at 8 and 12 months after inoculation. The data of real-time PCR analysis were used to calculate the persentage of infected plants, to count the average of $C$ Las titer on each rootstock/scion combinations and to obseve inconsistency between onset of symptoms and $C$ Las titers.

\subsection{Plant Height, Diameters of Rootstock and Scion Stem, and Ratio Scion/Rootstock Diameters}

Plant height, diameters of rootstock and scion stem were observed on 4, 8 and 12 months after treatment. Scionand rootstock diameters of seedlings were measured $5 \mathrm{~cm}$ above and $5 \mathrm{~cm}$ below the graft union, respectively, using a digital caliper.

\section{Results}

\subsection{Effect of Rootstock/Scion Combination on Huanglongbing Disease Intensity}

The success of transmission of $C$ Las in each rootstock/scions variety was not related to the rate of symptoms expression (Figure 1). 


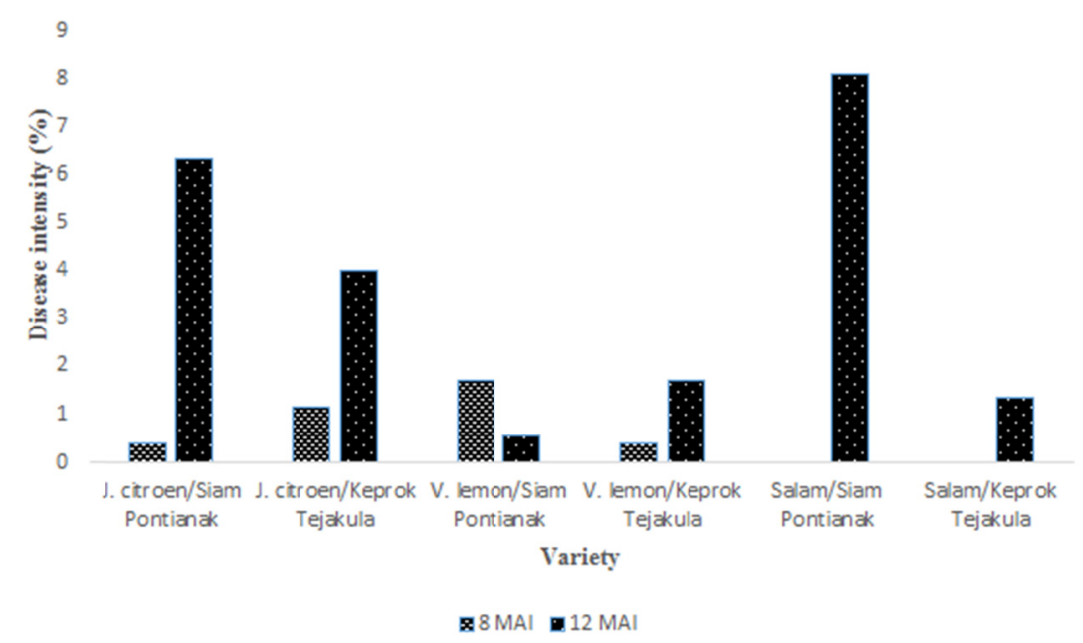

Figure 1. Huanglongbing disease intensity on each of rootstock/scion combination at 8 and 12 months after inoculation

All of rootstock/scion varieties in 4 months after $C$ Las inoculation was asymptomatic, while the low developing disease intensity was revealed at 8 months and 12 months. Non inoculated plants expressed $1.524 \%$ of disease intensity. The emergence of these symptoms on non inoculated plants occured by natural transmission of citrus psyllid from infected plants. The minor disease intensity might be caused by rainfall during observation.

\subsection{Candidatus Liberibacter Asiaticus (CLas) Titers by Real-Time PCR Analysis}

The presence of $C$ Las on most of inoculated plants could be detected at 8 months after inoculation by real-time PCR analysis, excluded on Volkamer lemon/'Siam Purworejo' (Table 2). Although, all plants of rootstock/scions combinations had been infected in 12 months after inoculation. Presence of $C$ Las in plant was unstabile during observation. Combinations of Japansche citroen/'Siam Purworejo' and 'Salam'/'Keprok Tejakula' showed the lowest infected plants in 8 months after inoculation, while the lowest infected plants of Volkamer lemon/'Siam Purworejo' and 'Salam'/'Keprok Tejakula' combinations were indicated in 12 months after inoculation.

Table 2. Percentage of plants infected by huanglongbing based on Ct value by real-time PCR analysis in 8 months and 12 months after inoculation

\begin{tabular}{|c|c|c|c|c|}
\hline \multirow{3}{*}{ Rootstock/Scion variety } & \multicolumn{4}{|c|}{ Plants infected by huanglongbing $(\%)^{*}$} \\
\hline & \multicolumn{2}{|c|}{ HLB inoculation } & \multicolumn{2}{|c|}{ Naturally infected by vector } \\
\hline & $8 \mathrm{MAI}$ & $12 \mathrm{MAI}$ & $8 \mathrm{MAI}$ & $12 \mathrm{MAI}$ \\
\hline Japansche citroen/Siam Purworejo & 100 & 100 & 40 & 100 \\
\hline Japansche citroen/Keprok Tejakula & 100 & 100 & 100 & 100 \\
\hline Volkamer lemon/Siam Purworejo & 80 & 100 & 60 & 60 \\
\hline Volkamer lemon/Keprok Tejakula & 100 & 100 & 100 & 100 \\
\hline Salam/Siam Purworejo & 100 & 100 & 100 & 100 \\
\hline Salam/Keprok Tejakula & 100 & 100 & 40 & 60 \\
\hline
\end{tabular}

Note. $* \mathrm{Ct}<36$ assumed huanglongbing infected plant, $\mathrm{Ct}>36$ assumed non infected plant (healthy).

The concentration of CLas bacteria on plants depended on the combination of rootstock/scion variety (Table 3). 
Table 3. CLas bacteria titers from six rootstock/scion combinations of huanglongbing inoculated and naturally infected by vector in 8 months and 12 months after inoculation

\begin{tabular}{|c|c|c|c|c|}
\hline \multirow{3}{*}{ Rootstock/Scion variety } & \multicolumn{4}{|c|}{ Cycle threshold $(\mathrm{Ct})$ values of $C \mathrm{Las}^{1}$} \\
\hline & \multicolumn{2}{|c|}{ Huanglongbing inoculation } & \multicolumn{2}{|c|}{ Naturally infected by vector } \\
\hline & $8 \mathrm{MAI}$ & $\mathrm{Ct} 12 \mathrm{MAI}$ & Ct 8 MAI & Ct 12 MAI \\
\hline Japansche citroen/Siam Purworejo & $29.22 \pm 4.75$ & $23.94 \pm 2.37$ & $31.46 \pm 3.00$ & $23.93 \pm 0.83$ \\
\hline Japansche citroen/Keprok Tejakula & $27.02 \pm 5.41$ & $23.514 \pm 1.45$ & $32.73 \pm 2.50$ & $28.57 \pm 54$ \\
\hline Volkamer lemon/Siam Purworejo & $31.83 \pm 3.53$ & $23.74 \pm 1.16$ & $35.05 \pm 1.62$ & $31.09 \pm 6.42$ \\
\hline Volkamer lemon/Keprok Tejakula & $32.56 \pm 2.47$ & $21.09 \pm 3.69$ & $34.63 \pm 0.48$ & $31.87 \pm 5.43$ \\
\hline Salam/Siam Purworejo & $29.31 \pm 5.25$ & $22.994 \pm 1.15$ & $34.36 \pm 1.09$ & $31.83 \pm 3.78$ \\
\hline Salam/Keprok Tejakula & $33.50 \pm 1.11$ & $21.32 \pm 0.74$ & $34.9 \pm 2.36$ & $32.67 \pm 4.51$ \\
\hline
\end{tabular}

Note. ${ }^{1} \mathrm{Ct}$ values of real-time PCR are means of five replicates \pm standard deviation from DNA $50 \mathrm{ng} / \mu 1$.

Volkamer lemon rootstocks which were grafted with 'Siam Purworejo' or 'Keprok Tejakula' scions and a combination of 'Salam'/'Siam Purworejo' had lower rates of CLas concentration than others in 8 months after inoculation, although all of rootstock/scion varieties showed almost the same bacterial concentration in 12 months after inoculation. Plant generated from Japansche citroen rootstock had relatively higher (lower $\mathrm{Ct}$ value) of bacterial concentration compared to other rootstock/scion combinations. This indicated that Japansche citroen rootstock was more susceptible to HLB than Volkamer lemon and 'Salam' rootstocks.

Almost all varieties of rootstock/scions showed presence of $C$ Las with various concentrations, although did not express symptoms of HLB. The inconsistency between symptoms and CLas concentration on the plant displayed in Figure 2. Combinations of 'Salam'/'Siam Purworejo' and 'Salam'/'Keprok Tejakula' which were inoculated by $C$ Las indicated the presence of bacteria, although they were symptomsless until eight months after inoculation, as well as Japansche citroen and Volkamer lemon rootstocks which were grafted with 'Keprok Tejakula' scion and combination of 'Salam'/'Siam Purworejo' which were infected naturally by vector (Diaphorina citri). Sixty percent of plants were symptomless at 8 months after treatment; however CLas was detected on $100 \%$ of asymptomatic plants in 12 months after inoculation.

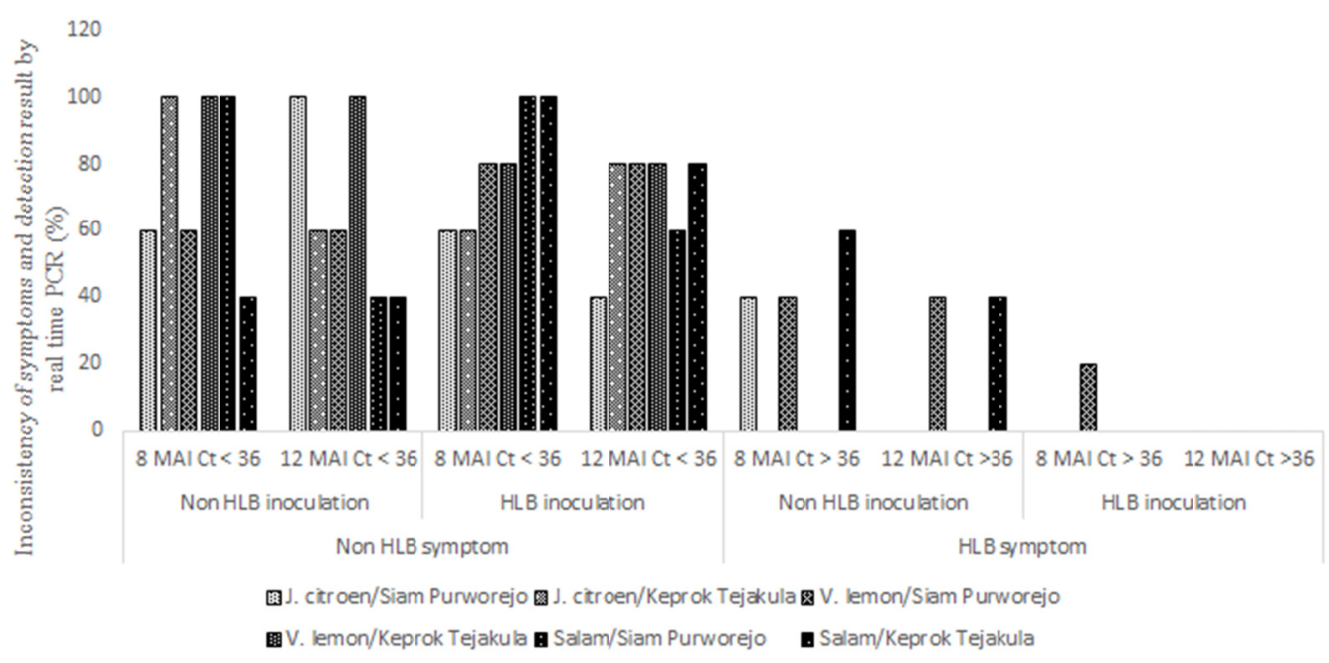

Figure 2. Inconsistency of huanglongbing symptoms and $C$ Las titers detection by real time PCR in 8 months and 12 months after inoculation

\subsection{Plant Height, Diameters of Rootstock and Scion Stem, and Ratio Scion/Rootstock Diameters}

$C$ Las infection had no effect on plant height rather than control plants (Table 4). 
Table 4. Plants height $(\mathrm{cm})$ of six rootstock/scion combinations of huanglongbing inoculated and naturally infected by vector in 4,8 and 12 months after treatments

\begin{tabular}{llll}
\hline \multirow{2}{*}{ Treatments } & \multicolumn{3}{c}{ Plant height $(\mathrm{cm})$} \\
\cline { 2 - 4 } & 4 MAI & 8 MAI & 12 MAI \\
\hline Pathogen inoculation & & & \\
Naturally infected by vector & $50.767 \mathrm{a}$ & $71.533 \mathrm{a}$ & $82.767 \mathrm{a}$ \\
Huanglongbing inoculation & $53.467 \mathrm{a}$ & $74.400 \mathrm{a}$ & $83.800 \mathrm{a}$ \\
\hline Rootstock/Scion variety & & & \\
Japansche citroen/Siam Purworejo & $44.700 \mathrm{~b}$ & $68.900 \mathrm{~b}$ & $76.100 \mathrm{c}$ \\
Japansche citroen/Keprok Tejakula & $48.500 \mathrm{~b}$ & $68.000 \mathrm{~b}$ & $75.900 \mathrm{c}$ \\
Volkamer lemon/Siam Purworejo & $62.500 \mathrm{a}$ & $83.200 \mathrm{a}$ & $91.200 \mathrm{ab}$ \\
Volkamer lemon/Keprok Tejakula & $63.000 \mathrm{a}$ & $82.600 \mathrm{a}$ & $95.200 \mathrm{a}$ \\
Salam/Siam Purworejo & $48.600 \mathrm{~b}$ & $70.100 \mathrm{~b}$ & $83.400 \mathrm{bc}$ \\
Salam/Keprok Tejakula & $45.400 \mathrm{~b}$ & $65.000 \mathrm{~b}$ & $77.900 \mathrm{c}$ \\
\hline
\end{tabular}

Note. Values followed by the different letter on the same treatments are significantly different based on DMRT (P $=0.05)$.

The highest growth was performed by seedling which grafted by Volkamer lemon rootstock. There was no interaction between pathogen inoculation and citrus varieties on height of citrus seedling until 12 months after inoculation.

Diameters of rootstock and scion stem on HLB inoculated plant showed significantly higher than control (Tables 5 and 6). Different scion varieties provided a significantly different effect on the diameter of rootstock stem. Stem of 'Keprok Tejakula' scion grafted on rootstock had smaller diameter of rootstock than 'Siam Purworejo' scion. There was no interaction between pathogen inoculation with a graft combination of scions/rootstock varieties to the diameter of rootstock and scions stem and also the ratio of diameter of scion/rootstock stem.

Table 5. Diameter of rootstock stem $(\mathrm{mm})$ of six combinations rootstock/scion of huanglongbing inoculated and naturally infected by vector in 4,8 and 12 months after inoculation

\begin{tabular}{llcc}
\hline \multirow{2}{*}{ Treatments } & \multicolumn{3}{c}{ Diameter of rootstock stem (mm) } \\
\cline { 2 - 4 } & $4 \mathrm{MAI}$ & $8 \mathrm{MAI}$ & $12 \mathrm{MAI}$ \\
\hline Pathogen inoculation & & & \\
Naturally infected by vector & $6.579 \mathrm{~b}$ & $10.804 \mathrm{~b}$ & $11.243 \mathrm{~b}$ \\
Huanglongbing inoculation & $7.282 \mathrm{a}$ & $11.671 \mathrm{a}$ & $12.188 \mathrm{a}$ \\
\hline Rootstock/Scion variety & & & \\
Japansche citroen/Siam Purworejo & $6.794 \mathrm{bc}$ & $11.329 \mathrm{~b}$ & $11.674 \mathrm{bc}$ \\
Japansche citroen/Keprok Tejakula & $6.178 \mathrm{~cd}$ & $10.305 \mathrm{c}$ & $10.871 \mathrm{~cd}$ \\
Volkamer lemon/Siam Purworejo & $7.961 \mathrm{a}$ & $12.432 \mathrm{a}$ & $13.031 \mathrm{a}$ \\
Volkamer lemon/Keprok Tejakula & $7.562 \mathrm{ab}$ & $11.848 \mathrm{ab}$ & $12.369 \mathrm{ab}$ \\
Salam/Siam Purworejo & $7.240 \mathrm{ab}$ & $11.557 \mathrm{ab}$ & $11.838 \mathrm{bc}$ \\
Salam/Keprok Tejakula & $5.848 \mathrm{~d}$ & $9.954 \mathrm{c}$ & $10.510 \mathrm{~d}$ \\
\hline
\end{tabular}

Note. Values followed by the different letter on the same treatments are significantly different based on DMRT (P $=0.05)$. 
Table 6. Diameters of scion stem $(\mathrm{mm})$ of six combinations rootstock/scion of huanglongbing inoculated and naturally infected by vector in 4,8 and 12 months after inoculation

\begin{tabular}{llcl}
\hline \multirow{2}{*}{ Treatments } & \multicolumn{3}{c}{ Diameter of scion stem $(\mathrm{mm})$} \\
\cline { 2 - 4 } & $4 \mathrm{MAI}$ & $8 \mathrm{MAI}$ & $12 \mathrm{MAI}$ \\
\hline Pathogen inoculation & & & \\
Naturally infected by vector & $5.338 \mathrm{~b}$ & $7.632 \mathrm{~b}$ & $8.357 \mathrm{~b}$ \\
Huanglongbing inoculation & $5.876 \mathrm{a}$ & $8.533 \mathrm{a}$ & $9.079 \mathrm{a}$ \\
\hline Rootstock/Scion variety & & & \\
Japansche citroen/Siam Purworejo & $5.371 \mathrm{~b}$ & $7.847 \mathrm{~b}$ & $8.374 \mathrm{~b}$ \\
Japansche citroen/Keprok Tejakula & $5.231 \mathrm{~b}$ & $7.633 \mathrm{~b}$ & $8.405 \mathrm{~b}$ \\
Volkamer lemon/Siam Purworejo & $6.026 \mathrm{ab}$ & $8.754 \mathrm{a}$ & $9.630 \mathrm{a}$ \\
Volkamer lemon/Keprok Tejakula & $6.716 \mathrm{a}$ & $9.337 \mathrm{a}$ & $10.051 \mathrm{a}$ \\
Salam/Siam Purworejo & $5.166 \mathrm{~b}$ & $7.429 \mathrm{~b}$ & $7.799 \mathrm{~b}$ \\
Salam/Keprok Tejakula & $5.131 \mathrm{~b}$ & $7.494 \mathrm{~b}$ & $8.049 \mathrm{~b}$ \\
\hline
\end{tabular}

Note. Values followed by the different letter on the same treatments are significantly different based on DMRT (P $=0.05$ ).

A graft compatibility of rootstock/scion which was expressed by the ratio of diameters of scion and rootstock stem after infection with CLas did not show significantly difference with the control. Although, the diameter of rootstock and scions stem was significantly different between inoculated plants and control (Table 7). This suggested that the pathogen inoculation did not affect against the suitability of a graft compatibility rootstock/scion. Combination of Japansche citroen rootstock with both scions showed insignificantly difference of rootstock/scion graft compatibility by Duncan Multiple Range Test 5\%. Meanwhile, the combination of the others rootstocks/scion resulted significantly different in a graft compatibility on the same rootstock with different scion, excluded Volkamer lemon rootstock in 12 months after inoculation. The ratio of rootstock/scions which was closer to 1 resulted in the balance of plant nutrients.

Table 7. Scion/rootstock ratio of six combinations rootstock/scion of huanglongbing inoculated and naturally infected by vector in 4,8 and 12 months after inoculation

\begin{tabular}{llcl}
\hline \multirow{2}{*}{ Treatments } & \multicolumn{3}{c}{ Scion/rootstock ratio } \\
\cline { 2 - 4 } & 4 MAI & 8 MAI & 12 MAI \\
\hline Pathogen inoculation & & $1.430 \mathrm{a}$ & $1.358 \mathrm{a}$ \\
Naturally infected by vector & $1.253 \mathrm{a}$ & $1.383 \mathrm{a}$ & $1.355 \mathrm{a}$ \\
Huanglongbing inoculation & $1.267 \mathrm{a}$ & & \\
Rootstock/Scion variety & & $1.452 \mathrm{~b}$ & $1.394 \mathrm{~b}$ \\
Japansche citroen/Siam Purworejo & $1.289 \mathrm{abc}$ & $1.367 \mathrm{bc}$ & $1.297 \mathrm{bc}$ \\
Japansche citroen/Keprok Tejakula & $1.209 \mathrm{bc}$ & $1.426 \mathrm{~b}$ & $1.355 \mathrm{bc}$ \\
Volkamer lemon/Siam Purworejo & $1.334 \mathrm{ab}$ & $1.269 \mathrm{c}$ & $1.230 \mathrm{c}$ \\
Volkamer lemon/Keprok Tejakula & $1.126 \mathrm{c}$ & $1.583 \mathrm{a}$ & $1.542 \mathrm{a}$ \\
Salam/Siam Purworejo & $1.436 \mathrm{a}$ & $1.344 \mathrm{bc}$ & $1.321 \mathrm{bc}$ \\
Salam/Keprok Tejakula & $1.168 \mathrm{bc}$ & $\mathrm{m}$ &
\end{tabular}

Note. Values followed by the different letter on the same treatments are significantly different based on DMRT (P $=0.05)$.

\section{Discussion}

Disease-free seedling should be used in the management of systemic disease-free citrus orchards. Inoculum reduction by elimination of symptomatic plants has been recommended world-widely to control HLB (Belasque et al., 2010), because until now there is no practical, routine and economically feasible method for early detection of HLB-infected trees. The intensity of the disease based on observation of huanglongbing symptoms and presence of CLas titer on different rootstock/scion combination indicated the level of tolerance to the disease. Almost all of rootstock/scion combination varieties contained CLas with different of CLas titers depending on the 
status of $C$ Las inoculation, rootstock/scions varieties and duration of plant infection. Blotchy mottle symptom was first found at 180 days after inoculation on the Autumn and 240 days after inoculation in Spring (Coletta-Filho et al., 2009).

Different from other disease such as soft rot (Joko et al., 2014), the appearance of HLB disease symptoms was not always associated with bacterial titers. Sometimes, asymptomatic plants had high titers of $C$ las, while symptomatic ones had low bacterial titers. The increasing degree of microscopic aberrations correlated with HLB symptoms development and CLas progression (Folimonova \& Anchor, 2010). The minor of disease symptoms caused by rainfall during the process of observation. Plants have better availability of nutrients and growth of new flush which gives plants more vigor and health to fight against HLB infection and reduce disease severity during rainfall. Symptomless plants with $C$ Las content have to be controlled in accordance with the spread of inoculum source through infected seedling. $\mathrm{Ca}$. L asiaticus expressed a less intense symptom development. However, its showed a high rate of pathogen transmission. On the contrary, $\mathrm{Ca}$. L. americanus was detected mainly in symptomic plants (Lopez et al., 2009). In other cases, there were infected plants because of natural transmission by psyllids vector. Preventing CLas infection by the psyllids and removing diseased trees are important on management of HLB, especially in the absensce of resistant or tolerant commercial citrus varieties and with no known cure for HLB (Belasque et al., 2010; Hall et al., 2013).

Tolerance to HLB was higher in trees grafted on certain rootstock. Volkamer lemon rootstock tended to show good growth performance when grafted on 'Siam Purworejo' and 'Keprok Tejakula' scions. Volkamer lemon rootstock trees also produced the highest cumulative yield and larger of 'Navalina' orange fruits amongst others (Forner-Giner et al., 2003). Rootstock vigor might influenced the shoot flushes of the scion variety. Therefore, availability of the preferential food for the psyllid was greater, effecting in higher dispersion of the bacteria. In the United States, higher incidence of the disease was reported in several scions grafted on Volkamer lemon rootstock, when compared to the same clones grafted on Rough lemon (Citrus jambhiri Lush.) and Swingle citrumelo (Poncirus trifoliata (L.) Raf. $\times$ Citrus paradisi Macfad.) (Stuchi \& Girardi, 2010). Other rootstocks had different tolerance to HLB in growth, yield and quality of trees in field (Bowman \& McCollum, 2015; Bowman et al., 2016). This indicated that there are meaningful differences between the rootstock tolerances to HLB. The selected rootstock which induces low vigor to the scions accompanied by high yield efficiency, could indirectly have a role to decrease the vector food so that reducing presence of HLB.

\section{Conclussion}

The huanglongbing symptoms appeared in 8 months after inoculation, excluded 'Salam' rootstock. All the plants which were inoculated with $C$ Las bacteria had a high bacterial titers (lower $\mathrm{Ct}$ ) in 12 months after inoculation. Emergence of disease symptoms on rootstock/scion combinations did not relate with bacterial titers. Height of infected plants was not affected by pathogen infection. Effect of CLas infection was found in diameter of rootstocks and scions stem, although compatibility of rootstock/scions was not affected. Both scion varieties grafted with Volkamer lemon rootstock had better growth than grafted with Japansche citroen and 'Salam' rootstocks based on observation of plant height, and diameter of rootstock and scion stem. Varieties of rootstock/scions combination influenced the level of plant tolerance to HLB on height inoculum density and endemic vector psyllids condition. Japansche citroen rootstock was more susceptible to HLB than Volkamer lemon and 'Salam' rootstocks.

\section{Acknowledgements}

The authors would like to thank Indonesian Agency for Agriculture Research and Development, Ministry of Agriculture, for the financial support.

\section{References}

Ahmad, K., Sijam, K., Hashim, H., Abdu, A., \& Rosli, Z. (2011). Assessment of citrus susceptibility towards Candidatus Liberibacter Asiaticus-Terengganu isolate based on vector and graft transmission tests. Journal of Agricultural Science, 3, 159-166. https://doi.org/10.5539/jas.v3n3p159

Albrecht, U., Fiehn, O., \& Bowman, K. D. (2016). Metabolic variations in different citrus rootstock cultivars associated with different responses to huanglongbing. Plant Physiology and Biochemistry, 107, 33-44. https://doi.org/10.1016/j.plaphy.2016.05.030

Albrecht, U., McCollum, G., \& Bowman, K. D. (2012). Influence of rootstock variety on huanglongbing disease development in field-grown sweet orange (Citrus sinensis [L.] Osbeck) trees. Scientia Horticulturae, 138, 210-220. https://doi.org/10.1016/j.scienta.2012.02.027 
Anonymous. (2002). Preparation of plant DNA using CTAB. In F. M. Ausubel, R. Brent, R. E. Kingston, D. D. Moore, J. G. Seidman, J. A. Smith, \& K. Struhl (Eds.), Short protocols in molecular biology: a compendium of methods from current protocols in molecular biology (5th ed., Vol. 1). John Wiley \& Sons. New York.

Bassanezi, R. B., Belasque Jr., J., \& Montesino, L. H. (2013). Frequency of symptomatic trees removal in small citrus blocks on citrus huanglongbing epidemics. Crop Protect., 52, 72-77. https://doi.org/10.1016/ j.cropro.2013.05.012

Belasque, J. J., Bassanezi, R. B., Yamamoto, P. T., Ayres, A. J., Tachibana, A., Violante, A. R., ... Bové, J. M. (2010). Lessons from huanglongbing management in S o Paulo State, Brazil. J. Plant Pathol., 92(2), 285-302.

Bowman, K. D., \& McCollum, G. (2015). Five new citrus rootstocks with improved tolerance to huanglongbing. HortScience, 50(11), 1731-1734.

Bowman, K. D., McCollum, G., \& Albrecht, U. (2016). Performance of 'Valencia' orange (Citrus sinensis [L.] Osbeck) on 17 rootstocks in a trial severely affected by huanglongbing. Scientia Horticulturae, 201, 355-361. https://doi.org/10.1016/j.scienta.2016.01.019

Coletta-Filho, H. D., Carlos, E. F., Alves, K. C. S., Pereira, M. A. R., Boscariol-Camargo, R. L., de Souza, A. A., \& Machado, M. A. (2009). In planta multiplication and graft transmission of Candidatus Liberibacter asiaticus revealed by Real-Time PCR. Eur. J. Plant Pathol., 126(1), 53-60. https://doi.org/10.1007/s10658-009-9523-2

Folimonova, S. Y., \& Achor, D. S. (2010). Early events of citrus greening (Huanglongbing) disease development at the ultrastructural level. Phytopathology, 100, 949-958. https://doi.org/10.1094/PHYTO-100-9-0949

Folimonova, S. Y., Robertson, C. J., Garnsey, S. M., Gowda, S., \& Dawson, W. O. (2009). Examination of the responses of different genotypes of citrus to huanglongbing (citrus greening) under different conditions. Phytopathology, 99, 1346-1354. https://doi.org/10.1094/PHYTO-99-12-1346

Forner-Giner, M. A., Alcaide, A., Primo-Millo, E., \& Forner, J. B. (2003). Performance of 'Navelina' orange on 14 rootstocks in Northern Valencia (Spain). Scientia Horticulturae, 98, 223-232. https://doi.org/10.1016/S0304-4238(02)00227-3

Hall, D. G., Gottwald, T. R., Stover, E., \& Beattie, G. A. C. (2013). Evaluation of management programs for protecting young citrus plantings from huanglongbing. HortScience, 48(3), 330-337.

Joko, T., Subandi, A., Kusumandari, N., Wibowo, A., \& Priyatmojo, A. (2014). Activities of plant cell wall degrading enzymes by bacterial soft rot of orchid. Archives of Phytopathology and Plant Protection, 47(10), 1239-1250. https://doi.org/10.1080/03235408.2013.838374

Lopes, S. A., \& Frare, G. F. (2008). Graft transmission and cultivar reaction of citrus to 'Candidatus Liberibacter americanus'. Plant Dis., 92, 21-24. https://doi.org/10.1094/PDIS-92-1-0021

Lopes, S. A., Bertolini, E., Frare, G. F., Martins, E. C., Wulff, N. A., Teixeira, D. C., ... Cambra, M. (2009). Graft transmission efficiencies and multiplication of 'Candidatus Liberibacter americanus' and ' $\mathrm{Ca}$. Liberibacter asiaticus' in citrus plants. Phytopathology, 99, 301-306. https://doi.org/10.1094/PHYTO99-3-0301

McCollum, G., Hilf, M., Irey, M., Luo, W., \& Gottwald, T. (2016). Susceptibility of sixteen citrus genotypes to 'Candidatus Liberibacter asiaticus'. Plant Dis., 100(6), 1080-1086. https://doi.org/10.1094/PDIS-08-150940-RE

Mckinney, H. H. (1923). Influence of soil temperature and moisture on infection of wheat seedlings by Helminthosporium sativum. J. Agric. Res., 26, 195-217.

Ramadugu, C., Keremane, M. L., Halbert, S. E., Duan, Y. P., Roose, M. L., Stover, E., \& Lee, R. F. (2016). Long-term field evaluation reveals huanglongbing resistance in citrus relatives. Plant Dis., 100, 1858-1869. https://doi.org/10.1094/PDIS-03-16-0271-RE

Shokrollah, H., Abdullah, T. L., Sijam, K., \& Abdullah, S. N. A. (2011). Potential use of selected citrus rootstocks and interstocks against huanglongbing disease in Malaysia. Crop Protect., 30, 521-525. https://doi.org/10.1016/j.cropro.2010.09.005

Stover, E., Inch, S., Richardson, M. L., \& Hall, D. G. (2016). Conventional citrus of some scion/rootstock combinations show field tolerance under high huanglongbing disease pressure. HortScience, 51(2), 127-132 
Stover, E., McCollum, G. T., Driggers, R., Lee, R., Shatters Jr., R., Duan, Y. P., ... Hall, D. G. (2015). Resistance and tolerance to huanglongbing in citrus. Acta Hort. (ISHS), 1065, 899-903. https://doi.org/10.17660/ActaHortic.2015.1065.111

Stuchi, E. S., \& Girardi, E. A. (2010). Use of horticultural practices in citriculture to survive Huanglongbing. Embrapa Cassava \& Fruits, Documentos 189. https://doi.org/10.13140/RG.2.1.4159.8802

Subandiyah, S., Iwanami, T., Tsuyumu, S., \& Ikki, H. (2000). Comparison of 16S RNA and 16S/23S intergenic region sequences among citrus greening organism in Asia. Plant Dis., 84, 15-18. https://doi.org/10.1094/ PDIS.2000.84.1.15

Zhou, L., Powell, C. A., Hoffman, M. T., Li, W., Fan, G., Liu, B., ... Duan, Y. P. (2011). Diversity and plasticity of the intracellular plant pathogen and insect symbiont "Candidatus Liberibacter asiaticus" as revealed by hypervariable prophage genes with intragenic tandem repeats. App. Environ.Microbiol., 77, 6663-6673. https://doi.org/10.1128/AEM.05111-11

\section{Copyrights}

Copyright for this article is retained by the author(s), with first publication rights granted to the journal.

This is an open-access article distributed under the terms and conditions of the Creative Commons Attribution license (http://creativecommons.org/licenses/by/4.0/). 